\title{
USING A DIFFERENT GROWTH MEDIUM GREATLY IMPROVES DISTINCTION OF Butyrivibrio fibrisolvens AND Pseudobutyrivibrio xylanivorans STRAINS BY THE CELLULAR FATTY ACIDS AND ALDEHYDES PROFILES
}

\author{
Maša ZOREC ${ }^{1}$, Maša VODOVNIK ${ }^{2}$, Romana MARINŠEK LOGAR ${ }^{2}$
}

Received October 22, 2010; accepted December 21, 2010. Delo je prispelo 22. oktobra 2010, sprejeto 21. decembra 2010.

\begin{abstract}
Using a different growth medium greatly improves distinction of Butyrivibrio fibrisolvens and Pseudobutyrivibrio xylanivorans strains by the cellular fatty acids and aldehydes profiles

A total of 11 ruminal strains currently assigned to Butyrivibrio fibrisolvens and Pseudobutyrivibrio xylanivorans were cultivated in two different media, rumen fluid containing M2 and short-chain fatty acid (SCFA) containing M330, and their cellular fatty acid methyl esters (FAME) and dimethylacetals (DMA) were analyzed using gas chromatography. A comparison of the FAME/DMA compositions revealed that the difference in SCFA contents in the growth medium induced a pronounced quantitative effect on the cellular branched-chain fatty acid and aldehydes proportions only in the P. xylanivorans strains. This study shows that FAME/DMA analysis is a powerful chemotaxonomic tool in the group of phenotypically similar rumen butyrivibria especially when the influence of the growth medium is evaluated.
\end{abstract}

Key words: microbiology / anaerobic bacteria / rumen / Butyrivibrio / Pseudobutyrivibrio / FAME / DMA

\section{INTRODUCTION}

The Butyrivibrio group of bacteria comprises Grampositive anaerobic butyrate-producing rods isolated mainly from the rumen of cattle and sheep. Although butyrivibrios are phenotypically very coherent, phylogenetic analyses revealed their polyphyletic origin (Willems et al., 1996) and currently five rumen species are asserted: Butyrivibrio fibrisolvens, B. hungatei, B. proteoclasticus, Pseudobutyrivibrio ruminis and P. xylanivorans (Bryant and Small, 1956; van Gylswyk et al., 1996; Kopečný et al., 2003; Moon et al., 2008). The analysis of long-chain fatty acids (FA) is frequently used method in bacterial chemo-
Uporaba različnih gojǐ̌č bistveno olajša ločevanje sevov Butyrivibrio fibrisolvens in Pseudobutyrivibrio xylanivorans na osnovi profilov maščobnih kislin in aldehidov

Skupno smo gojili 11 vampnih sevov iz vrst Butyrivibrio fibrisolvens in Pseudobutyrivibrio xylanivorans $\mathrm{v}$ dveh različnih gojiščih: $\mathrm{v}$ M2 z vampnim sokom in $\mathrm{v}$ M330 z mešanico kratkoverižnih maščobnih kislin (SCFA). S plinsko kromatografijo smo analizirali njihove metilne estre celičnih maščobnih kislin (FAME) in dimetilacetale (DMA). Primerjava sestave FAME/ DMA je razkrila, da razlika $\mathrm{v}$ vsebnosti SCFA $\mathrm{v}$ gojišču povzroči izrazit kvantitativen učinek na deleže celičnih razvejanih maščobnih kislin in aldehidov le pri sevih vrste $P$. xylanivorans. Naša raziskava dokazuje, da lahko FAME/DMA analizo učinkovito uporabljamo $\mathrm{v}$ kemotaksonomiji fenotipsko podobnih butirivibrijev z ustreznim ovrednotenjem vpliva gojišča.

Ključne besede: mikrobiologija / anaerobne bakterije / vamp / Butyrivibrio / Pseudobutyrivibrio / FAME / DMA

taxonomy as it is rapid and simple, and the results are usually in accordance with the results of genotypic analyses (Vandamme et al., 1996). Taxonomic significance is based on their highly regulated synthesis and the cellular FA composition is defined by the type of multienzyme complex present which gives a stabile profile in a particular strain (Lu et al., 2004). Cellular FA composition is affected also by environmental factors, but these effects can either be avoided with the standardization of growth conditions or adequately evaluated.

In the anaerobic bacteria a special class of membrane lipids, plasmalogens, is present that bear an etherlinked alkyl chain at the $s n-1$ position of glycerol (lately

1 Univ. of Ljubljana, Biotechnical Fac., Dept. of Animal Science, Groblje 3, SI-1230 Domžale, Slovenia, Ph.D., e-mail: masa.zorec@bf.uni-lj.si

2 Same address as 1, Ph.D. 
reviewed by Goldfine, 2010). During the methylation step for the gas chromatography (GC) analysis these fatty aldehydes are converted to dimethyl acetals (DMA). Fatty aldehyde composition usually mirrors that of the FA (Goldfine and Panos, 1971). The role of fatty aldehydes in bacterial cell membrane is still not clear: it was proposed that they serve as an additional path for NADH regeneration and can be protective against reactive oxygen species (Paltauf, 1994).

Membrane branched-chain FA are synthesized from two types of precursors: most of bacteria use branchedchain amino acids, but some ruminal species are capable of utilizing exogenously supplied branched-chain SCFA (Kaneda, 1991). In this study we wish to ascertain whether we could selectively manipulate cellular FA and aldehyde composition of the strains by feeding precursors that favoured the production of branched-chain FA. It was shown previously that in the B. fibrisolvens type strain the FA and aldehyde composition did not changed substantially when the cells were grown in the presence of SCFA (Moore et al., 1994). Using a different media was also successfully applied in the differentiation of Bacillus anthracis and B. cereus strains (Lawrence et al., 1991).

\section{MATERIALS AND METHODS}

Bacteria were grown at $37^{\circ} \mathrm{C}$ under anaerobic conditions in a rumen fluid containing growth medium M2 and DSMZ medium 330 without rumen fluid. In M330 mixture of SCFA was added instead of rumen fluid (1.7 $\mathrm{mL} / \mathrm{L}$ of acetic acid, $0.6 \mathrm{~mL} / \mathrm{L}$ of propionic acid, $0.4 \mathrm{~mL} / \mathrm{L}$ of butyric acid and $0.1 \mathrm{~mL} / \mathrm{L}$ of valeric, iso-butyric, iso-

Table 1: List of bacterial strains Preglednica 1: Seznam bakterijskih sevov

\begin{tabular}{lll}
\hline species & strain & isolated by \\
\hline $\begin{array}{l}\text { Butyrivibrio } \\
\text { fibrisolvens }\end{array}$ & $3071 \mathrm{~T}$ & M.P. Bryant \\
& LFO5 & L. Fanedl \\
JK642 & J. Kopečný \\
& LFO4 & L. Fanedl \\
& JK651 & J. Kopečný \\
Pseudobutyrivibrio & Mz5T & M. Zorec \\
& CE51 & N.O. van Gylswyk \\
& JK663 & J. Kopečný \\
& LFO3 & L. Fanedl \\
& DSM 10317 & N.O. van Gylswyk \\
& DSM 10296 & J.M. Leatherwood \\
& Mz8 & M. Zorec \\
\hline
\end{tabular}

Table 2: Short-chain fatty acids (SCFA) content ( $m M)$ in the growth media

Preglednica 2: Vsebnost kratkoverižnih maščobnih kislin (mM) $v$ gojišču

\begin{tabular}{lll}
\hline & SCFA content $(\mathrm{mM})$ & \\
\hline & $\mathrm{M} 2$ & $\mathrm{M} 330$ \\
\hline acetic acid & 22.3 & 40.1 \\
propionic acid & 4.4 & 8.4 \\
butyric acid & 2.2 & 4.5 \\
valeric acid & 0.2 & 0.9 \\
iso-butyric acid & 0.2 & 1.1 \\
iso-valeric acid & 0.2 & 1.7 \\
\hline
\end{tabular}

valeric and DL-2-methyl-buytric acid each). The GC analysis of SCFA in the growth media is shown in Table 2.

Samples were prepared from freeze dried cells of the overnight cultures. For FAME/DMA GC analysis their methyl esters were prepared (Dionisi, 1999). The method with $\mathrm{HCl}$ in methanol was chosen where freezedried cells were transferred into Hach tube and $500 \mu \mathrm{L}$ of hexane was added. The sample was then transesterified using $1 \mathrm{~mL}$ of methanolic hydrochloric acid (1.5M) and $1 \mathrm{~mL}$ of methanol at $80^{\circ} \mathrm{C}$ for $10 \mathrm{~min}$. The reaction was stopped in ice-cold water. $2 \mathrm{~mL}$ of miliQ water was added and vigorously shaken for $1 \mathrm{~min}$. The upper organic phase was transferred to GC vial, flushed with nitrogen gas and stored at $-20^{\circ} \mathrm{C}$ until analysis. A Shimadzu GC$14 \mathrm{~A}$ gas chromatograph equipped with a flame-ionization detector was used. Helium was used as carrier gas. An Equity-1 capillary column (30 m length, $0.25 \mathrm{~mm}$ i.d.) coated with $100 \%$ poly-dimethyl-siloxane $(0.25 \mu \mathrm{m}$ film thickness) was purchased from Supelco (28045-U). The column was operated at $150{ }^{\circ} \mathrm{C}$ for $4 \mathrm{~min}$, and then the temperature was increased at $4^{\circ} \mathrm{C} / \mathrm{min}$ to $250^{\circ} \mathrm{C}$ and held for $10 \mathrm{~min}$. One microliter of each sample solution was manually injected. The peaks were recorded with Shimadzu Chromatopac C-R6A integrator. The components were quantified through their relative peak areas and identified by their equivalent chain length (ECL) factors (Mjøs, 2003). For reference standard calibration mixes were used (BAME, Supelco, 47080-U and DMA C16:0, Sigma, H7391).

\section{RESULTS AND DICUSSION}

The FAME/DMA profiles of the tested strains were very complex consisting of more than 20 different components (Table 3). In rumen fluid medium M2 the most prevalent FAME/DMA in both species were C16:0, DMA C18:1 c11, DMA C16:0 and DMA C16:1 c9. Their pro- 


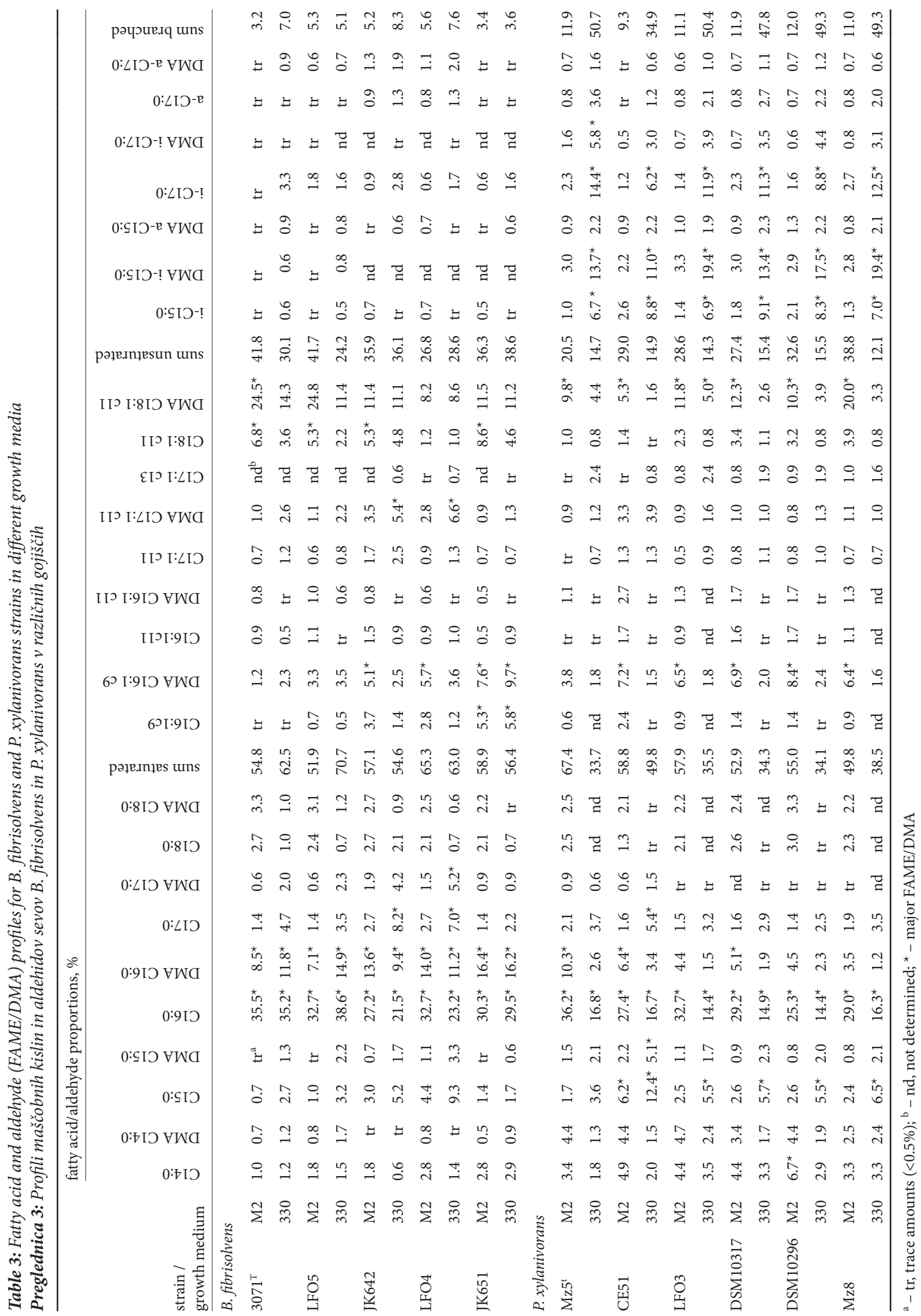


portions were above or closely to $5 \%$ in all of the analyzed strains. Additionally, in the B. fibrisolvens strains C18:1 c11 was identified as the major FA (except in the strain LFO4). When comparing the sum proportions, straight-chain saturated and unsaturated FAME/DMA amounts were similar in both species, while branched chain FAME/DMA were slightly more abundant in $P$. xylanivorans strains (on average B. fibrisolvens $4.5 \%$ and P. xylanivorans $11.2 \%)$. Although the sum proportion of branched-chain FA and aldehydes between the species is statistically significant $(\mathrm{P}<0.0001)$, the differentiation of the species by the major FA and aldehydes is impossible.

Therefore, the strains were grown in medium M330 with higher amounts of SCFA (Table 2) in order to induce changes in the proportions of the major FA and aldehydes. In the B. fibrisolvens strains the $\mathrm{FA}$ and aldehyde profiles remains stable, with slight increase of odd-numbered FA and aldehydes due to larger amounts of propionic and valeric acid in the growth medium (Ingram et al., 1977). On the other hand, in the P. xylanivorans strains higher amounts of SCFA in the growth medium provoked marked increase in the branched chain FAME/DMA proportions with corresponding decrease in straight chain FAME/DMA. Interestingly, the sum of branched chain FA and aldehydes increased at the same extent as the concentration of SCFA in the growth medium. This demonstrates that in the P. xylanivorans strains SCFA in the medium serve as direct precursors for the synthesis of the membrane FA and aldehydes (Kaneda, 1991).

In P. xylanivorans palmitic acid (C16:0) remains major constituent, but its proportion was halved in all strains. As major FA and aldehydes DMA i-C15:0, i-C17:0 and i-C15:0 were also identified. The increase in odd-numbered straight chain saturated FA and aldehydes (C15:0, DMA C15:0, C17:0) was seen with their even-numbered counterparts decrease (C14:0, C16:0, C18:0 and corresponding aldehydes). The proportions of all unsaturated FAME/DMA were lower comparing with cells grown in rumen fluid supplemented medium.

Cellular FA manipulation with growth medium composition can be exploited in many ways. Rosen and Hackette (1972) altered E. coli outer membrane to release more enzymes after osmotic shock in oleate-supplemented medium. Recently, Listeria monocytogenes impaired growth at refrigeration temperatures was achieved by growing cells in SCFA enriched medium (Julotok et al., 2010). Increased production of extracellular endoglucanase and exoglucanase, enzymes of cellulase complex, in fungus Neurospora crassa was succeeded also by adding oleic acid (Yazdi et al., 1990). In our case, the strains of P. xylanivorans produce highly active xylanases that have biotechnological potential (Čepeljnik et al., 2003). Re- sults of this study suggest that the membrane FA composition of the P. xylanivorans strains is dependent on the growth conditions and therefore release of xylanases to the extracellular matrix can be facilitated by decreasing membrane fluidity with growing in branched SCFA enriched medium.

The effect of the SCFA in the growth medium is shown in the strains of two species. For the taxonomical purposes further analysis in other butyrivibrio-like species is needed to show whether SCFA-dependence is the genus trait.

\section{CONCLUSIONS}

Based on above mentioned results we can conclude that the growth media with higher branched SCFA content is more suitable for the differentiation between $B$. fibrisolvens and $P$. xylanivorans. Only the later species increases the content of branched FA and aldehyde in its cellular profiles and differentiation is facilitated by identifying only a few major FA and aldehydes. Namely, the major cellular FA and aldehydes in SCFA-supplemented growth medium are in B. fibrisolvens strains C16:0 (29.6\% $\pm 7.4 \%)$, DMA C16:0 $(12.7 \% \pm 2.8 \%)$ and DMA C18:1 c11 $(11.3 \% \pm 2.0 \%)$, and in P. xylanivorans strains C16:0 $(15.5 \% \pm 1.2 \%)$, DMA i-C15:0 $(15.7 \% \pm 3.5 \%)$, i-C $17: 0$ $(10.9 \% \pm 2.9 \%)$ and $\mathrm{i}-\mathrm{C} 15: 0(7.8 \% \pm 1.1 \%)$.

\section{REFERENCES}

Bryant M.P., Small N. 1956. The anaerobic monotrichous butyric acid-producing curved rod-shaped bacteria of the rumen. Journal of Bacteriology, 72: 16-21

Dionisi F., Golay P.-A., Elli M., Fay L.B. 1999. Stability of cyclopropane and conjugated linoleic acids during fatty acid quantification in lactic acid bacteria. Lipids, 34, 10: 1107-1115

Čepeljnik T., Zorec M., Kostanjšek R., Nekrep F.V., Marinšek Logar R. 2003. Is Pseudobutyrivibrio xylanivorans $\mathrm{Mz}^{\mathrm{T}}$ suitable as a probiotic? : an in vitro study. Folia Microbiologica, 48, 3: 339-345

Goldfine H. 2010. The appearance, disappearance and reappearance of plasmalogens in evolution. Progress in Lipid Research, 49: 493-498

Goldfine H., Panos C. 1971. Phospholipids of Clostridium butyricum. IV. Analysis of the positional isomers of monounsaturated and cyclopropane fatty acids and alk - 1'-enyl ethers by capillary column chromatography. Journal of $\mathrm{Li}$ pid Research, 12: 214-220

Ingram L.O., Chevalier L.S., Gabbay E.J., Ley K.D., Winters K. 1977. Propionate-induced synthesis of odd-chain-length fatty acids by Escherichia coli. Journal of Bacteriology, 131, 3: $1023-1025$ 
Julotok M., Singh A.K., Gatto C., Wilkinson B.J. 2010. Influence of fatty acid precursors, including food preservatives, on the growth and fatty acid composition of Listeria monocytogenes at 37 and $10^{\circ} \mathrm{C}$. Applied and Environmental Microbiology, 76, 5:1423-1432

Kaneda T. 1991. Iso- and anteiso-fatty acids in bacteria: biosynthesis, function, and taxonomic significance. Microbiological Reviews, 55, 2: 288-302

Mjøs S.A. 2003. Identification of fatty acids in gas chromatography by application of different temperature and pressure programs on a single capillary column. Journal of Chromatography A, 1015: 1515-161

Moon C.D., Pacheco D.M., Kelly W.J., Leahy S.C., Li D., Kopečný J., Attwood G.T. 2008. Reclassification of Clostridium proteoclasticum as Butyrivibrio proteoclasticus comb. nov., a butyrate-producing ruminal bacterium. International Journal of Systematic and Evolutionary Microbiology, 58: 2041-2045

Moore L.V.H., Bourne D.M., Moore W.E.C. 1994. Comparative distribution and taxonomic value of cellular fatty acids in thirty-three genera of anaerobic Gram-negative bacilli. International Journal of Systematic Bacteriology, 44, 2: 338-347

Kopečný J., Marinšek Logar R., Zorec M., Mrazek J., Kobayashi Y. 2003. Butyrivibrio hungatei sp. nov., and Pseudobutyrivibrio xylanivorans sp. nov., butyrate-producing bacteria from the rumen. International Journal of Systematic and Evolutionary Microbiology, 53: 201-209
Lawrence D., Heitefuss S., Seifert H.S.H. 1991. Differentiation of Bacillus anthracis from Bacillus cereus by gas chromatographic whole-cell fatty acid analysis. Journal Clinical Microbiology, 29, 7: 1508-1512

Lu Y.-J., Zhang Y.-M., Rock C.O. 2004. Product diversity and regulation of type II fatty acid synthases. Biochemistry and Cell Biology, 82: 145-155

Paltauf F. 1994. Ether lipids in biomembranes. Chemistry and Physics of Lipids, 74: 101-139

Rosen B.P., Hackette L. 1972. Effects of fatty acid substitution on the release of enzymes by osmotic shock. Journal of Bacteriology, 110, 3: 1181-1189

Vandamme P., Pot B., Gillis M., De Vos P., Kersters K., Swings J. 1996. Polyphasic taxonomy, a consensus approach to bacterial systematics. Microbiological Reviews, 60, 2: 407-438

van Gylswyk N.O., Hippe H., Rainey F.A. 1996. Pseudobutyrivibrio ruminis gen. nov., sp. nov., a butyrate-producing bacterium from the rumen that closely resembles Butyrivibrio fibrisolvens in phenotype. International Journal of Systematic Bacteriology, 46, 2: 559-563

Willems A., Amat-Marco M., Collins M.D. 1996. Phylogenetic analysis of Butyrivibrio strains reveals three distinct groups of species within the Clostridium subphylum of the Grampositive bacteria. International Journal of Systematic Bacteriology, 46, 1: 195-199

Yazdi M.T., Woodward J.R., Radford A. 1990. The cellulase complex of Neurospora crassa: activity, stability and release. Journal of General Microbiology, 136: 1313-1319 